\title{
Wide-spread occurrence and clonal variation in viruses which cause lysis of a cosmopolitan, eukaryotic marine phytoplankter, Micromonas pusilla
}

\author{
Matthew T. Cottrell, Curtis A. Suttle* \\ Marine Science Institute, Department of Marine Science, The University of Texas at Austin, Po Box 1267, Port Aransas, \\ Texas 78373-1267, USA
}

\begin{abstract}
Seven clonal isolates of viruses which cause lysis of the eukaryotic, naked, photosynthetic flagellate Micromonas pusilla (Prasinophyceae) were isolated from the coastal waters of New York, Texas, California and British Columbia, as well as the oligotrophic waters of the central Gulf of Mexico. The viruses are large polyhedrons (ca $115 \mathrm{~nm}$ dia.) lacking tails, and are morphologically similar to a previously described virus (MPV) which infected $M$. pusilla. Restriction fragment analysis of the DNA from these clones using EcoRI revealed unique banding patterns, demonstrating that each of the clones (including 3 that were isolated from the same water sample) were genetically different. Summation of the 17 to 26 visible fragments from the restriction digests, for each of the clones, yielded estimated genome sizes of 77 to 110 kilobase pairs. In contrast, only 4 different types of viruses could be recognized based on the molecular weights of the major proteins. In field samples the concentrations of viruses causing lysis of $M$. pusilla were found to be spatially and temporally variable, ranging from $<20$ to $4.6 \times 10^{6}$ infective units $1^{-1}$ Our results demonstrate that this genetically diverse but morphologically similar group of viruses is widespread in nature. As viral infections propagate rapidly when host density is high, the presence of these viruses may place constraints on the maximum density that $M$. pusilla could reach in nature. If viruses infecting other phytoplankton taxa are similarly widespread then they are probably a major factor maintaining diversity in phytoplankton communities, and are also likely important players in nutrient and energy cycling.
\end{abstract}

\section{INTRODUCTION}

Recently, a number of studies (Bergh et al. 1989, Proctor \& Fuhrman 1990, Suttle et al. 1990) have reported concentrations of viral particles in marine waters in excess of $10^{7} \mathrm{ml}^{-1}$ in a variety of marine habitats. Yet, little is known about this abundant and apparently diverse natural virus community or its role in aquatic ecosystems. Nonetheless, observations from transmission electron microscopy (TEM) (e.g. Pienarr 1976, Johnson \& Sieburth 1982, Sieburth et al. 1988, Proctor \& Fuhrman 1990) and from culture studies (Spencer 1963, Hidaka 1977, Moebus 1980, Suttle et al. 1990) have indicated that heterotrophic bacteria, cyanobacteria and eukaryotic algae are infected by viruses in seawater.

\footnotetext{
- Addressee for correspondence
}

Virtually nothing is known about the geographic distribution or the genetic diversity of viruses which infect phytoplankton in the sea. In order to explore these unknowns we have isolated from a variety of geographic locations viruses which infect a common algal host. The eukaryotic, naked photosynthetic flagellate Micromonas pusilla (Prasinophyceae) was chosen as the experimental organism for a number of reasons. First, a virus which lyses this alga had been isolated from waters adjacent to the British Columbia coast (Mayer \& Taylor 1979, Waters \& Chan 1982). Second, M. pusilla has been reported to occur in the central (Hoepffner \& Haas 1990) and western (Furuya \& Marumo 1983) Pacific Ocean, the eastern Atlantic Ocean (Manton \& Parke 1960), the fjords of Norway (Throndsen 1976), the Caribbean Sea (Throndsen 1973), the western Baltic Sea (Jochem 1990), and the Strait of Georgia (Cochlan et al. 1990). Third, we initially isolated viruses infecting this 
widely distributed host from Texas and New York coastal waters which suggested that the viruses might be widely distributed as well.

This is the first detailed study comparing viral clones that infect a widely distributed and abundant component of marine phytoplankton communities. We isolated 7 viral clones from 5 widely separated regions of the Atlantic and Pacific Oceans, as well as the Gulf of Mexico, and compared them with respect to their morphology, DNA restriction fragment banding patterns, genome sizes, and molecular weights of major proteins. We also obtained estimates of the concentration of viruses which lyse Micromonas pusilla in the water samples from which the viral clones were obtained. Our results demonstrate that viruses which lyse $M$. pusilla are geographically widespread and genetically diverse.

\section{MATERIALS AND METHODS}

Algal cultures. Micromonas pusilla (UTEX 991, Plymouth 27) was obtained from the Culture Collection of Algae at the University of Texas at Austin (Starr \& Zeikus 1987). Algal cultures were grown in ESAW, an enriched artificial seawater medium (Harrison et al. 1980) modified by the addition of $5 \mathrm{mM}$ Tris- $\mathrm{HCl}(\mathrm{pH}=$ 7.7 ) and $10 \mathrm{nM} \mathrm{Na} \mathrm{NeO}_{3} . \mathrm{M}$. pusilla was found to have an obligate $\mathrm{Se}$ requirement. Cultures were grown in borosilicate containers $(25 \times 150 \mathrm{~mm}$ screw-cap test tubes, 2 I Erlenmeyer flasks capped with beakers, or 91 carboys plugged with cotton bungs) at $18^{\circ} \mathrm{C}$ under continuous light (Philipps F96712/CW/VHO) at 100 umol m $\mathrm{m}^{2} \mathrm{~s}^{-1}$. Culture biomass was monitored via in vivo chlorophyll fluorescence using a Turner Designs fluorometer or by cell counts of Lugol's-fixed (Parsons et al. 1984) samples using a hemocytometer.

Study sites. Water from a number of geographically distant locations was screened for the presence of viruses infecting Micromonas pusilla. The study sites included productive coastal waters on the eastern, western, and southern coasts of North America and the oligotrophic waters of the Gulf of Mexico. Dates and locations of sampling are given in Table 1

The Peconic Bay estuary (PB) is located at the eastern-most end of Long Island, New York, USA. Peconic Bay is vertically well mixed with little or no seasonal stratification. Phytoplankton primary productivity ranges from 162 to $213 \mathrm{~g} \mathrm{C} \mathrm{m}^{-2} \mathrm{yr}^{-1}$ (Bruno et al. 1980), similar to other estuaries of the northwest Atlantic coast. The largest source of freshwater input is nonpoint sources (Hardy 1976) and the salinity near the head of the estuary ranges seasonally between 23.5 and 29.5 ppt (Bruno et al. 1980).

Both the Marine Science Institute pier lab (PL) and boat basin are located on the south side of the Aransas
Pass located at the northern end of Mustang Island, Texas, USA. The Pass allows the exchange of water between the Gulf of Mexico and a lagoon between the mainland and the series of barrier islands which include Mustang Island. Depending on tide, wind, and rainfall, the water at this location can be representative of oligotrophic offshore water or productive estuarine water.

The Strait of Georgia (SG) is a partially enclosed basin which lies between the mainland of British Columbia and the southern half of Vancouver Island, Canada. The salinity in the Strait is diluted considerably by freshwater input from the Fraser River. Near the location where these samples were taken, temperature and salinity ranged between ca 7 to $17^{\circ} \mathrm{C}$ and 12 to 29 ppt respectively. The chlorophyll concentration of the mixed depth averages several $u g l^{-1}$ (Stockner et al. 1979)

Scripps pier (SP) is located in La Jolla, California, USA, and juts out past the surf zone into the Pacific Ocean. Salinities in the region are generally high (>33 ppt) and representative of conditions farther out in the California Bight, whereas temperature and chlorophyll values are variable and strongly influenced by upwelling events (Wyllie \& Lynn 1971, Owen 1974).

The samples from the central Gulf of Mexico were collected along a transect that intersected a warm-core eddy which had broken away from the Gulf of Mexico Loop Current. Chlorophyll concentrations at $20 \mathrm{~m}$ reached a maximum of $0.05 \mathrm{ug} \mathrm{l}^{-1}$ along the transect and a deep chiorophyll maximum with chlorophyll concentrations as high as $0.34 \mu \mathrm{g} \mathrm{l}^{-1}$ was present at each station along the transect (Biggs 1991).

Virus isolation. Generally, 11 surface water samples were collected at each location described above and transported back to the laboratory where they were filtered and screened for viruses as outlined below. Water samples from the oligotrophic Gulf of Mexico were collected from Niskin-bottle samples taken aboard the RV 'Gyre' on Cruise 90G-15 during the period 13 to 15 October 1990. Water samples $(250 \mathrm{ml}$ ) were collected from Stns 3, 5, 7, 9, 11, 13, and 15 at depth intervals of ca $20 \mathrm{~m}$ between 40 and $105 \mathrm{~m}$ below the surface. The cruise track and station locations were chosen to sample warm-core eddy $Q$ in the Gulf of Mexico (Biggs 1991)

Water samples from which viruses were isolated were filtered under vacuum $(<30 \mathrm{~cm} \mathrm{Hg})$ either through $47 \mathrm{~mm}$ diameter, 0.2 um pore-size (Nuclepore) polycarbonate membrane filters (oceanic samples) or $47 \mathrm{~mm}$ diameter, $0.45 \mu \mathrm{m}$ pore-size (Millipore) polyvinylidene difluoride (PVD) Durapore filters (coastal samples). Viruses infecting Micromonas pusilla were previously shown to remain infective after filtration through polycarbonate and PVD membranes (Suttle et 
al. 1991). Samples from the cruise were transported back to the laboratory in polyethylene screw cap bottles at $4^{\circ} \mathrm{C}$.

The titer of viruses which lyse Micromonas pusilla in the filtered water samples was estimated using 3 or 4 ten-fold dilution steps in ESAW. Known volumes (0.1 to $1.0 \mathrm{ml}$ ) of each dilution were added to exponentially growing cultures of $M$. pusilla. Five replicate cultures were used to assay each dilution step and the viral titer was estimated using the most probable number (MPN) method (Taylor 1962). The detection limit of the method was 0.02 viruses $\mathrm{ml}^{-1}$. Repeated titering of a stock viral solution indicated that the concentration of infective viruses can be estimated in a reproducible manner with this method (coefficient of variation = $45 \%$ ).

Viral clones were isolated by adding 0.2 infective units of a titered seawater sample to 20 Micromonas pusilla cultures. The probability that a culture received 1 virus was 0.1637 and therefore would be expected to occur with a frequency of 3.274 out of 20 cultures. The fact that no more than 4 of the 20 cultures lysed during any of the cloning experiments suggests that we were successful in obtaining lysates initiated by a single virus (data not shown). The probability that a culture received 2 or more viruses was 0.0176 and therefore would be expected to occur with a frequency of 0.352 out of 20 cultures.

Virus amplification and purification. Each Micromonas pusilla virus (MPV) clone was amplified by adding $40 \mathrm{ml}$ of lysate into an exponentially growing $8 \mathrm{l}$ culture of $M$. pusilla. After about $3 \mathrm{~d}$ the lysed culture was prefiltered through either a $142 \mathrm{~mm}$ diameter $0.45 \mu \mathrm{m}$ pore-size Durapore filter or a $0.2 \mu \mathrm{m}$ pore-size polycarbonate $Q R$ Nuclepore cartridge $\left(2.3 \mathrm{~m}^{2}\right.$ of filtration area). The viruses were collected from the filtered lysate by ultrafiltration through either a $100000 \mathrm{MW}$ cutoff hollow-fiber or $30000 \mathrm{MW}$-cutoff spiral Amicon cartridge filter, and the retentate $(160 \mathrm{ml})$ centrifuged at $7700 \mathrm{rpm}(7087 \times g)$ for $20 \mathrm{~min}$ in an SS34 rotor (Sorvall) to pellet the small amount of bacteria and cellular debris not retained by the prefilter. The viruses were then pelleted from the supernatant by either centrifuging at $9200 \mathrm{rpm}(10117 \times \mathrm{g})$ for $90 \mathrm{~min}$ in an SS34 rotor or at $17000 \mathrm{rpm}(38400 \times \mathrm{g})$ for $30 \mathrm{~min}$ in an AH-629 rotor (Sorvall). The glassy pellet was resuspended in $50 \mathrm{mM}$ Tris- $\mathrm{HCl}(\mathrm{pH}=7.8)$. Pure MPV DNA could be extracted from samples processed in this manner. The restriction fragment banding pattern of DNA isolated from viruses purified with this protocol was the same as that obtained from viruses which had been further purified on a sucrose gradient. In order to isolate the viral proteins it was necessary to further purify the viral material on 10 to $40 \% \mathrm{w} / \mathrm{v}$ sucrose gradients made up in $50 \mathrm{mM}$ Tris-HCl $(\mathrm{pH}=7.8)$. The samples
(1 to $3 \mathrm{ml}$ ) were centrifuged at $17000 \mathrm{rpm}$ for $15 \mathrm{~min}$ in an $\mathrm{AH}-629$ rotor and a single band containing infective viruses recovered from the gradient. The band material was diluted about 10 -fold with $50 \mathrm{mM}$ Tris- $\mathrm{HCl}(\mathrm{pH}=$ 7.8 ) and the virus was once again collected by ultracentrifugation to remove most of the sucrose.

Isolation of viral DNA and restriction enzyme analysis. The procedure of Maniatis et al. (1982) was used for the extraction of the DNA. Samples $(0.5$ to $1.0 \mathrm{ml}$ ) were incubated for $15 \mathrm{~min}$ at $68^{\circ} \mathrm{C}$ in the presence of sodium dodecylsulfate to disrupt the viral proteins and then extracted with phenol, phenol/ chloroform (1:1), and chloroform. The final aqueous phase was adjusted to $0.1 \mathrm{M}$ sodium chloride and the DNA precipitated by the addition of 2 volumes of icecold $95 \%$ ethanol and incubation at $-20^{\circ} \mathrm{C}$ for $2 \mathrm{~h}$.

Viral DNA was digested with ECoRI restriction enzymes (Promega) following the suppliers' procedure. The DNA fragments were separated on $0.5 \%$ agarose gels in Tris-borate EDTA (TBE) buffer (Maniatis et al. 1982) and Hind III-digested lambda DNA was used to establish the relationship between distance migrated and fragment size in base pairs.

Sodium dodecylsulphate (SDS)-polyacrylamide gel electrophoresis (PAGE). Viruses purified on sucrose gradients were disintegrated by boiling for $10 \mathrm{~min}$ in sample buffer (Laemmli 1970). The peptides were separated by electrophoresis on a $12 \%$ polyacrylamide gel at $200 \mathrm{~V}$ and silver stained (Wray et al. 1981). SDSPage standards (Bio-Rad), 10000 to $100000 \mathrm{MW}$, were used for molecular weight calibration.

Transmission electron microscopy. Lysates were prepared for TEM by centrifuging $0.22 \mu \mathrm{m}$ Duraporefiltered lysates at $20000 \mathrm{rpm}(50400 \times \mathrm{g})$ for $30 \mathrm{~min}$ in a SW40 rotor (Beckman). Pellets were resuspended in $100 \mu l$ of ESAW and the viral particles transferred to carbon-coated copper grids by floating the grids on drops of the virus suspension for $20 \mathrm{~min}$. The grids were then stained ( $2 \mathrm{~s}$ ) with $2 \%$ aqueous Uranyl Acetate and photographed at a magnification of $72000 \times$ on an Hitachi HU11-E transmission electron microscope. Particle diameters were estimated by measuring the images on the negatives and dividing by the magnification.

\section{RESULTS}

\section{Lysis of cultures by virus and in vivo fluorescence assay}

All of the viral clones caused lysis of Micromonas pusilla. Cultures to which viruses were added at a virus to host ratio of 1 showed a decrease in growth rate after about 24 h relative to control cultures to which viruses were not added. Cell lysis occurred in infected cultures 


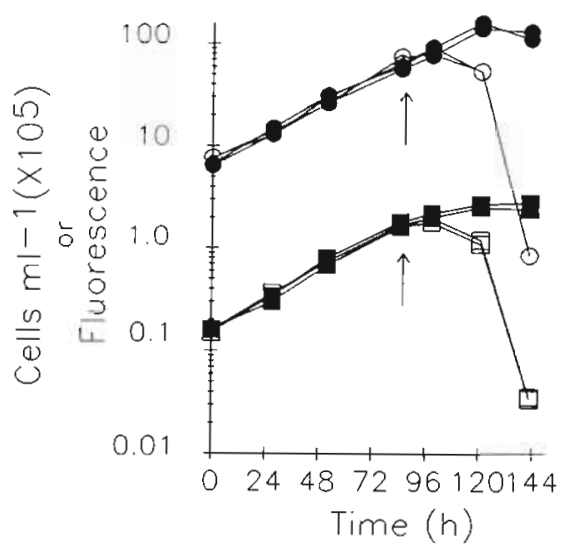

Fig. 1. Micromonas pusilla. Growth curves determined from in vivo chlorophyll fluorescence $(\square, \square)$ and cell counts $(\bullet, 0)$ Arrow indicates where one of the virus clones (MPV-PL1) was added to two of the cultures (open symbols) at a virus to host ratio of 1,0. Control cultures to which viruses were not added are shown as filled symbols

after about $36 \mathrm{~h}$ (Fig, 1), and was apparent whether growth was monitored by cell counts or in vivo fluorescence. Screening cultures for lysis by in vivo fluorescence allowed us to routinely monitor the large number of cultures required to conduct these experiments.

\section{Virus distribution}

We isolated viruses which lyse Micromonas pusilla from a wide range of environments representative of estuarine, coastal and oceanic habitats. Water samples obtained from Peconic Bay, Gulf of Mexico, Pier Lab in the Aransas Pass, Scripps Pier, Strait of Georgia, and the UT Boat Basin contained concentrations of viruses which lyse $M$. pusilla ranging from not detectable to $4600 \mathrm{ml}^{-1}$ (Table 1). The highest concentrations occurred in the small boat harbor at the University of Texas Marine Science Institute (UT Boat Basin) and the lowest in the oligotrophic waters of the central Gulf of Mexico. Virus concentrations were also temporally variable with concentrations of 3 and $4600 \mathrm{ml}^{-1}$ estimated in the UT Boat Basin at different times.

We assayed 34 water samples taken from 7 stations at ca 43 n mile intervals along a transect across a warmcore eddy in the Gulf of Mexico and were able to detect virus in only 1 water sample. The detection limit in these assays was $0.02 \mathrm{ml}^{-1}$. The thermal structure along the transect showed that we sampled water from outside the eddy, as well as water inside the eddy and the frontal region between the two. We sampled water above, below, and within the deep chlorophyll maximum which was present at all the stations (Biggs 1991). Interestingly, the 1 water sample from which we were able to isolate a virus which lyses Micromonas pusilla was taken from the deep chlorophyll maximum in the area of the front.

\section{Characteristics of viruses}

Transmission electron microscopy of positively stained preparations of the 7 viral clones revealed particles with maximum diameters ranging from 104 to $118 \mathrm{~nm}$ with an average of $113 \mathrm{~nm}$. No morphological differences were apparent between clones. The viruses appeared to be polyhedral and tailless (Fig. 2).

The structural proteins of the 7 viral clones were

Table 1. Concentrations of viruses lysing Micromonas pusilla in water samples collected from different locations. For the Gulf of Mexico stations, discrete samples were taken at each of the depths indicated

\begin{tabular}{|c|c|c|c|c|}
\hline Location & & Depth $(\mathrm{m})$ & Date of collection & Titer $^{\mathrm{a}}\left(\mathrm{MPN} \mathrm{ml} \mathrm{l}^{-1}\right)$ \\
\hline $\begin{array}{l}\text { Peconic Bay } \\
\text { Gulf of Mexico }\end{array}$ & $\left(40^{\circ} 00^{\prime} \mathrm{N}, 72^{\circ} 30^{\circ} \mathrm{W}\right)$ & Surface & 25 Jun 1990 & 90 \\
\hline $\operatorname{Stn} 3$ & $\left(27^{\circ} 20^{\prime} \mathrm{N}, 92^{\circ} 00^{\prime} \mathrm{W}\right)$ & $40,60,75,90,105$ & 13 Oct 1990 & Not detectable \\
\hline $\operatorname{Stn} 5$ & $\left(27^{\circ} 00^{\prime} \mathrm{N}, 91^{\circ} 19^{\prime} \mathrm{W}\right\}$ & $40,60,75,90,105$ & 14 Oct 1990 & Not detectable \\
\hline Stn 7 & $\left(26^{\circ} 40^{\prime} \mathrm{N}, 90^{\circ} 40^{\prime} \mathrm{W}\right)$ & $20,40,60,75,90,105$ & 14 Oct 1990 & Not detectable \\
\hline Stn 9 & $\left(26^{\circ} 20^{\prime} \mathrm{N}, \quad 89^{\circ} 59^{\prime} \mathrm{W}\right)$ & 40,60 & 14 Oct 1990 & Not detectable \\
\hline Stn 9 & $\left(26^{\circ} 20^{\prime} \mathrm{N}, 89^{\circ} 59^{\prime} \mathrm{W}\right)$ & 76 & 14 Oct 1990 & 0.1 \\
\hline $\operatorname{Stn} 9$ & $\left(26^{\circ} 20^{\prime} \mathrm{N}, 89^{\circ} 59^{\prime} \mathrm{W}\right)$ & 90,105 & 14 Oct 1990 & Not detectable \\
\hline Stn 11 & $\left(25^{\circ} 59^{\prime} \mathrm{N}, 89^{\circ} 20^{\prime} \mathrm{W}\right)$ & $20,60,75,90,105$ & 14 Oct 1990 & Not detectable \\
\hline Stn 13 & $\left(25^{\circ} 40^{\prime} \mathrm{N}, 88^{\circ} 40^{\prime} \mathrm{W}\right)$ & $40,60,75,90,105$ & 15 Oct 1990 & Not detectable \\
\hline Stn 15 & $\left(25^{\circ} 19^{\prime} \mathrm{N}, 88^{\circ} 00^{\prime} \mathrm{W}\right)$ & $60,75,90,110$ & 15 Oct 1990 & Not detectable \\
\hline Strait of Georgia & $\left(49^{\circ} 18^{\prime} \mathrm{N}, 124^{\circ} 11^{\prime} \mathrm{W}\right)$ & Surface & Sep 1990 & 9 \\
\hline Pier Lab & $\left(27^{\circ} 50^{\prime} \mathrm{N}, 97^{\circ} 04^{\prime} \mathrm{W}\right)$ & Surface & 31 Oct 1990 & 10 \\
\hline Scripps Pier & $\left(32^{\circ} 45^{\prime} \mathrm{N}, 117^{\circ} 15^{\prime} \mathrm{W}\right)$ & 0.5 & 31 Oct 1990 & 9 \\
\hline UT Boat Basin & $\left(27^{\circ} 50^{\prime} \mathrm{N}, \quad 97^{\circ} 04^{\prime} \mathrm{W}\right)$ & Surface & 24 May 1990 & 3 \\
\hline UT Boat Basin & $\left(27^{\circ} 50^{\prime} \mathrm{N}, \quad 97^{\circ} 04^{\prime} \mathrm{W}\right)$ & Surface & 10 Mar 1991 & 4600 \\
\hline
\end{tabular}




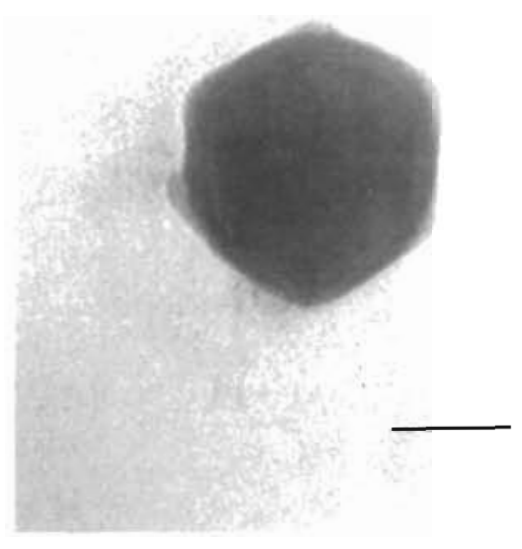

Fig. 2. MPV-PB5 positively stained with uranyl acetate and observed by transmission electron microscopy. Scale bar $=$ $50 \mathrm{~nm}$

analyzed by SDS polyacrylamide gel electrophoresis. All 7 clones contained at least 3 major proteins which appeared as distinct bands (Fig. 3). The viruses probably contain more than 3 proteins since more bands are visible when a larger sample is loaded into the gel. For example, clone SP1 produces lysates with titers about 10 times higher than the other clones (data not shown) and clearly contains more than 3 proteins. In addition, peptides of less than 21500 daltons $(21.5 \mathrm{kDa})$ are visible in preparations with especially low background (i.e. GM1), but may be hidden in preparations which had high background even after 1 purification on a sucrose density gradient (i.e. PL1).

The molecular weights of the major proteins varied among clones (Fig. 3). Based upon the molecular weights of the major proteins the 7 clones could be separated into 4 types (Table 2). Type I includes 2 clones from Peconic Bay (PB5, PB7) and the clone isolated from Southern California (SP1). The major proteins from these clones have molecular weights of 48.7 , 47.9 , and $44.6 \mathrm{kDa}$. Type II includes the third clone from Peconic Bay (PB8) whose major proteins have molecular weight of $54.4,48.7$, and $44.6 \mathrm{kDa}$. Note that Type I and Type II share peptides of 48.7 and $44.6 \mathrm{kDa}$. Type III includes the clone isolated from the central Gulf of Mexico (GM1) whose major proteins have molecular weights of $51.8,47.9$, and $44.6 \mathrm{kDa}$; again note that Type III shares the $44.6 \mathrm{kDa}$ peptide with Types I and II. Type IV includes the clones isolated from Aransas Pass (PL1) and the Strait of Georgia (SG1) whose major proteins have molecular weights of 55.8 , 50.7 , and $45.1 \mathrm{kDa}$. These proteins are not shared by any other clones (Table 2).

EcoRI restriction endonuclease digests of the DNA of

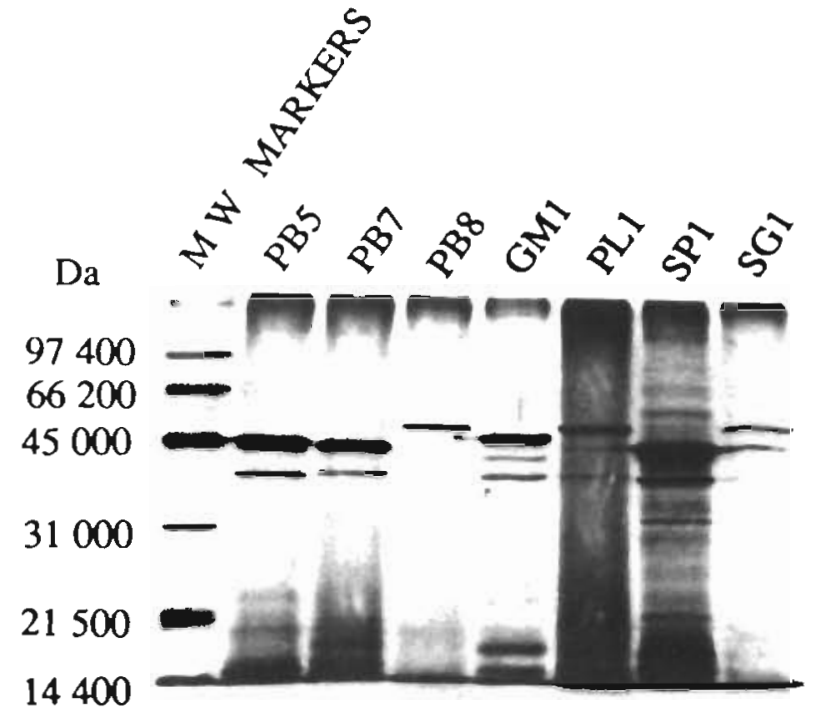

Fig. 3. Silver-stained polyacrylamide gel of proteins from the 7 viral clones infecting Micromonas pusilla. PB5, PB7, and PB8 were isolated from Peconic Bay, New York. Clones GM1 and PL1 were isolated from the central Gulf of Mexico and coastal waters of Texas respectively. SP1 was isolated from the waters off Southern California and SG1 was isolated from waters near British Columbia. Molecular weights of the standards are given in daltons (Da)

Table 2. Estimates of the molecular weights of the major proteins, size of the genomes and number of restriction fragments from an EcoRI digest of the viral genomes for each of the viral clones examined. Based on the protein banding patterns the virus clones could be classified into 4 types

\begin{tabular}{|c|c|c|c|c|}
\hline Clone & $\begin{array}{c}\text { Major } \\
\text { protein } \\
\text { (kDa) }\end{array}$ & Type & $\begin{array}{c}\text { Genome } \\
\text { size } \\
\text { (kbp) }\end{array}$ & Fragments \\
\hline MPV'-PB5 & $\begin{array}{l}48.7 \\
47.9 \\
44.6\end{array}$ & I & 99 & 19 \\
\hline MPV-PB7 & $\begin{array}{l}48.7 \\
47.9 \\
44.6\end{array}$ & I & 77 & 21 \\
\hline MPV-PB 8 & $\begin{array}{l}54.4 \\
48.7 \\
44.6\end{array}$ & II & 80 & 17 \\
\hline MPV-GM1 & $\begin{array}{l}51.8 \\
47.9 \\
44.6\end{array}$ & III & 104 & 26 \\
\hline MPV-PL1 & $\begin{array}{l}55.8 \\
50.7 \\
45.1\end{array}$ & IV & 84 & 24 \\
\hline MPV-SP1 & $\begin{array}{l}48.7 \\
47.9 \\
44.6\end{array}$ & I & 101 & 23 \\
\hline MPV-SG1 & $\begin{array}{l}55.8 \\
50.7 \\
45.1\end{array}$ & IV & 110 & 25 \\
\hline
\end{tabular}




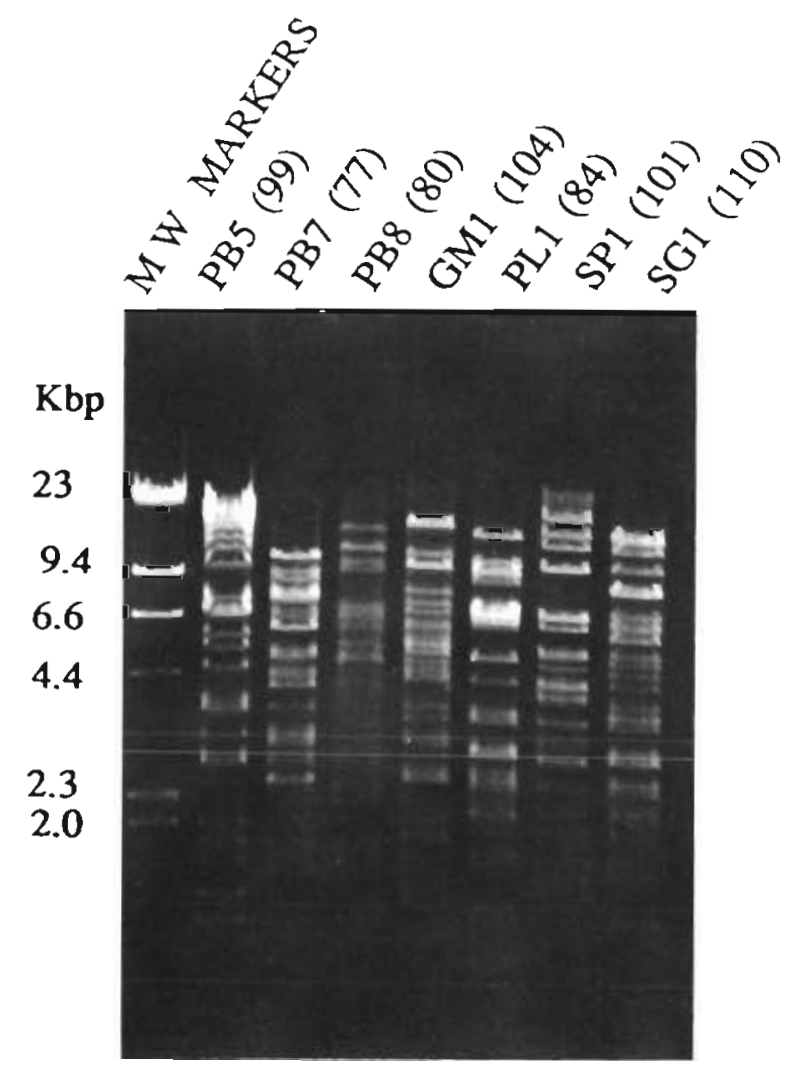

Fig. 4. Agarose gel electrophoresis of EcoRI restriction enzyme digests of DNA from 7 clones of viruses which lyse Micromonas pusilla. Clone designation of the isolates are as in Fig. 3. Estimated genome sizes from summing the restriction fragments are shown in parentheses

the 7 clones revealed 17 to 26 visible bands (Fig. 4). Each of the clones had a unique restriction fragment banding pattern including the 3 clones isolated from a single $1 \mathrm{l}$ water sample collected from Peconic Bay (PB5, PB7, PB8). Repeated amplification of the same viral clone demonstrated that restriction fragment banding patterns were conserved within a clone (data not shown). Summation of the EcoRI fragments yielded estimates of the genome sizes of the individual clones from 77 and $110 \mathrm{kbp}$ (Table 2). It should be noted that because of co-migrating restriction fragments genome sizes may be underestimated when based on the summation of restriction fragment sizes.

\section{DISCUSSION}

Several important findings emerged from our study. First, viruses infecting Micromonas pusilla are geographically wide-spread and occur in the coastal waters of the Pacific and Atlantic Oceans, as well as the Gulf of Mexico. Second, virus concentrations were different between geographic locations, and were different temporally at the same location. Third, no 2 virus clones were identical based upon ECoRI restriction fragment banding patterns. This included clones that were isolated from the same water sample. Fourth, based on the molecular weight of the viral proteins the 7 clones fell into 4 phenotypes. However, 2 of the 4 phenotypes were isolated from the same water sample. Fifth, no morphological differences were observed among clones. These observations are discussed in further detail below.

We cannot distinguish our viruses from the virus isolated by Mayer \& Taylor (1979). The virus they isolated was large (ca $130 \mathrm{~nm}$ ), hexagonal in profile and lacked a distinctive tail-like or other external structure (Mayer 1979). Their isolate of this virus was capable of lysing strains of Micromonas pusilla isolated from the English Channel, the coastal waters off Baja California, the coastal waters of British Columbia, and the NE Pacific at Weather Ship P It would not lyse any other algal taxa they tested (Mayer 1978). They did not conduct any biochemical investigations of the virus which is no longer in culture $(F$. J R. Taylor pers. comm.). Therefore, we are calling these viruses Micromonas pusilla virus (MPV) as well. On the other hand, the viruses we have isolated are easily distinguishable from the Chlorella viruses which are the only other well-characterized viruses infecting a eukaryotic alga. The latter are polyhedrons of about $175 \mathrm{~nm}$ in diameter, containing more than 50 structural proteins and having a genome of $333 \mathrm{kbp}$ (Van Etten et al. 1991).

\section{Comparisons among clones}

Restriction enzyme analysis of the DNA from the 7 clonal isolates showed that the genome of each clone is different from the others, although the 7 clones do share some phenotypic characteristics. They all lyse Micromonas pusilla and are tailless polyhedra with a diameter of about $115 \mathrm{~nm}$. The molecular weights of the major viral proteins vary among clones, but are not as variable as the restriction fragment patterns. In addition, clones which share major proteins of equal molecular weight have different restriction fragment banding patterns. The differences in restriction fragment banding patterns between clones may be due to differences in nucleotide sequences of their genomes. Our current interpretation of this result is that each of the 7 viral clones is a different strain of virus which lyses $M$. pusilla, but lacking more detailed information about the genomes, we cannot say at this time how closely related these clones might be. We are currently examining the genomes more closely. The existence of conserved regions among the genomes would lend support to our tentative conclusion based on the 
phenotypic similarity among these clones that they represent a group of closely related viruses.

The diversity of genotypes among clones of MPV, indicated by the restriction endonuclease analysis, is not unique to this eukaryotic algal virus. It is possible to isolate from nature many clones of viruses which infect an exosymbiotic Chlorella-like alga. Restriction enzyme analysis of these clones shows that each has a different restriction fragment banding pattern (Van Etten et al. 1985, Schuster et al. 1986, Zhang et al. 1988). It has also been demonstrated that some bacteriophages also exist in nature as populations with high clonal diversity. For example, it is possible to isolate from nature phages which are $\phi \times 174$-like with respect to having the same sized single stranded circular genome, icosahedral particle morphology, similar particle density, and the same number of proteins with approximately the same molecular weights (Godson 1974). Godson (1974) isolated 4 classes (called the Gphages) of these $\phi \times 174$-like phages and showed that while the genomes of phages G4, G6, G13, and G14 will form DNA heteroduplexes with $\phi X 174$ DNA, the resulting heteroduplexes contain regions of at least $24 \%$ base sequence mismatch and appeared as single stranded loops when viewed with TEM. A similar examination of T7-related phages using restriction enzyme analysis led Studier (1980) to the conclusion that during the evolution of the T7-related phages a highly successful morphology and genetic functional organization is conserved while the sequence of nucleotides in the DNA is plastic and can vary widely.

Studier's conclusion seems reasonable, but many questions remain unanswered. For example, what is the source of the genetic diversity observed in presumably closely related viral clones? Point mutations are the accepted mechanism by which base sequences of genes are modified, but DNA/DNA interactions such as homologous or illegitimate recombination which move homologous or nonhomologous sequences between viruses may be the prime accelerators of the evolution of bacteria and their viruses (Reanney \& Ackermann 1982). Studies of the lambdoid phages using heteroduplexing reveal that the DNA of phages like lambda and $\phi 80$ have regions of near-perfect homology interspersed with regions of total nonhomology. Examination of the nucleotid sequence of the genomes of phages $\mathrm{T} 3$ and $\mathrm{T} 7$ reveals regions of high similarity abutting regions of much lower similarity (Beck et al. 1989). It has been suggested that recombinations among ancestors of $\mathrm{T} 3$ and $\mathrm{T} 7$ gave rise to this pattern of sequence similarity and dissimilarity (Beck et al. 1989).

It would be interesting to examine the similarities and differences among the genomes of these algal viruses and to determine the potential for recombina- tion between these viruses under controlled laboratory conditions to assess whether recombination might be a mechanism by which they evolve. The probability that a single Micromonas pusilla cell would encounter 2 viral particles at the same time is certainly low given the titers of viruses we observed. Co-infection would seem to be a possible but inefficient mechanism by which recombination might take place between these viruses in the sea. On the other hand, if MPV can exist as a provirus within $M$. pusilla, there may be a number of $M$. pusilla cells in the sea which already contain a copy of the MPV genome. Recombination between a provirus and the genome of a free viral particle could be an efficient mechanism for recombination between different MPV genomes in the sea.

\section{Ecological implications}

The results of this study greatly extend previous observations of the presence of viral pathogens of phytoplankton in the sea, and the ecological implications posed by these results are significant. Viruses infecting Micromonas pusilla are widespread in nature. In fact, every coastal seawater sample that we have screened has contained viruses which cause lysis of $M$. pusilla. This must pose strict controls on the densities that can be maintained in M. pusilla populations. For example, Wiggins \& Alexander (1985) found that rapid propagation of viruses infecting Escherichia coli occurred when host density exceeded about $10^{4} \mathrm{ml}^{-1}$. At significantly lower densities the probability of a virus encountering a suitable host dictates that the infection propagates at a much slower rate. Hence, it would appear to be very unlikely that densities of $M$. pusilla could significantly exceed about $10^{4} \mathrm{ml}^{-1}$ in the presence of the viral pathogen. Interestingly, this is approximately the same maximum density that has been reported for $M$. pusilla populations in field samples (Cochlan et al. 1990). However, virus-resistant strains of $M$. pusilla may exist in nature which are not represented in culture collections and which would not be affected by the presence of the lytic virus. If host-specific viral pathogens do exist for each phytoplankton species then viral infection is the only mechanism that is required to maintain diversity in phytoplankton communities (sensu Hutchinson 1961). This is not unreasonable as viral pathogens infecting a variety of ecologically important phytoplankton taxa have been demonstrated to occur in seawater (Suttle et al. 1990). This leads to another significant ecological question in terms of the structure of phytoplankton communities, namely 'What are the mechanisms that allow phytoplankton to escape viral pathogens and form blooms?

The phenotypic and genotypic diversity observed 
among viruses infecting Micromonas pusilla (even within the same water sample) also poses interesting ecological and evolutionary questions. The phenotypic differences among clones may be under selective pressures. The nature of the selective agents is unknown, although obvious candidates would be phenotypic and physiological differences among the hosts. However, one cannot exclude the possibility of other factors being important (e.g. loss processes). Alternatively, the different phenotypes may all have equivalent fitness so that the differences between them are selectively neutral.

This study clearly demonstrates that, while widespread, viruses infecting Micromonas pusilla have spatially variable concentrations. In coastal waters concentrations were typically a few to less than $100 \mathrm{ml}^{-1}$; however, in one instance a titer of $4600 \mathrm{ml}^{-1}$ was observed. In contrast, in oligotrophic oceanic waters only one of 36 samples had a titer as high as $0.1 \mathrm{ml}^{-1}$. In the other 35 samples MPV was not detected. Clearly, some mechanism is operating to regulate the density of viruses which lyse $M$. pusilla in nature. Intuitively, as the virus is apparently highly host-specific (Mayer 1978) the density of $M$. pusilla must be important. We do not have estimates of host density from the samples from which viruses were isolated, but others (Throndsen 1973, 1976, Furuya \& Marumo 1983, Cochlan et al. 1990, Hoepffner \& Haas 1990, Jochem 1990, Harrison et al. 1991) have observed that $M$. pusilla is relatively abundant in coastal waters and particularly in subsurface chlorophyll maxima at coastal and offshore stations. This is consistent with our observations of higher viral titers in coastal waters. Furthermore, the sample from which MPV-GM1 was isolated was taken from the subsurface chlorophyll maximum near the western front of the warm-core eddy. Not surprisingly, these results suggest that populations of viruses which infect M. pusilla are found in environments where the alga has been shown to be abundant.

Concentrations of viruses infecting Micromonas pusilla also varied widely at a single location. This was demonstrated by the ca 1000 -fold difference in viral titre between 2 water samples collected from the same location on separate occasions (Table 2). Such large changes in the abundance of viruses infecting $M$. pusilla indicates that loss and production processes of the viruses are not necessarily tightly coupled. Nonetheless, it remains to be determined what the important factors are which control the distribution and abundance of these viruses in the sea.

If the cosmopolitan distribution and variability in titre of viruses infecting Micromonas pusilla are typical of viruses which infect other phytoplankton then such viruses are likely important players in nutrient and energy cycles in aquatic ecosystems.
Acknowledgements. This research was sponsored by grants from the Office of Naval Research (Grant No. N00014-90-J$1280\}$ and the Texas A \& M University Sea Grant College Program, supported through NOAA (Grant No. NA89AA-DSG139). Dr D. C. Biggs graciously arranged for our participation on a National Science Foundation- and Texas A \& M University-sponsored cruise (90G-15) and provided us with summarized data from that voyage. We gratefully acknowledge the assistance of Dr W. Cochlan, Dr T S. Cottrell and L and H. Hansen-McIntyre who kindly provided water from a variety of locations from which viruses were subsequently isolated, and A. M. Chan for assistance in the laboratory. The comments of Dr J. L. Van Etten improved the manuscript. Contribution no. 817 of the Marine Science Institute. University of Texas at Austin.

\section{LITERATURE CITED}

Bergh, O., Borsheim, K. Y., Bratbak, G., Heldal, J. (1989). High abundance of viruses found in aquatic environments Nature, Lond. 340: 467-468

Beck, P. J., Gonzalez, S., Ward, C. L., Molineaux, I. J. (1989). Sequence of bacteriophage T3 DNA from Gene 2.5 through gene 9. J. mol. Biol. 210: 687-701

Biggs, D. C. (1991). Gulf of Mexico hydrographic data. TechniCal Report 90-01-T of the Department of Oceanography of Texas A \& M University, College Station, Texas

Bruno, S. F., Taker, R. D., Sharma, G. M. (1980). Dynamics of phytoplankton productivity in the Peconic Bay estuary. Long Island. Estuar coast. Shelf Sci. 10: 247-263

Cochlan, W. P., Harrison, P. J., Clifford, P. J., Yin, K. (1990). Observations on double chlorophyll maxima in the vicinity of the Fraser River plume, Strait of Georgia, British Columbia. J. exp. mar. Biol. Ecol. 143: 139-149

Furuya, K.. Marumo, R. (1983). The structure of the phytoplankton community in the subsurface chlorophyll maxima in the western North Pacific Ocean. J. Plankton Res. 5: $393-406$

Godson, G. N. (1974). Evolution of $\phi X 174$. Isolation of four new $\phi X 174$-like phages and comparison with $\phi X 174$. Virology 58: 272-289

Hardy, C. D. (1976). A preliminary description of the Peconic Bay estuary. MSRC Special Report 3, Marine Sciences Research Center, State University of New York, Stony Brook

Harrson, P. J., Waters, R. E., Taylor, R. J. R. (1980). A broad spectrum artificial seawater medium for coastal and open ocean phytoplankton. J. Phycol. 16: 28-35

Harrison, P. J., Clifford, P. J., Cochlan, W. P., Yin, K., St. John, M. A., Thompson, P. A., Sibbald, M. J., Albright, L. J. (1991). Nutrient and phytoplankton dynamics in the Fraser River plume, Strait of Georgia, British Columbia. Mar Ecol. Prog. Ser 70: 291-304

Hidaka, T (1977). Detection and isolation of marine bacteriophage systems in the southwestem part of the Pacific Ocean. Men. Fac. Fish. Kagoshima Univ. 26: 55-62

Hoepffner, V., Haas, L. W (1990). Electron microscopy of nanoplankton from the North Pacific Central Gyre. J. Phycol. 26: $421-439$

Hutchinson. G. E. (1961). The paradox of the plankton. Am. Nat. 95: 137-145

Jochem, F. J. (1990). On the seasonal occurrence of autotrophic naked nanoflagellates in Kiel Bight, western Baltic. Estuar. coast. Shelf Sci. 31. 189-202 
Johnson, P. W. Sieburth, J. McN. (1982). In-situ morphology and occurrence of eukaryotic phototrophs of bacterial size in the picoplankton of estuarine and oceanic waters. J. Phycol. 18: 318-327

Laemmli, U. K. (1970). Cleavage of structural proteins during the assembly of the head of bacteriophage T4. Nature. Lond. $227 \cdot 680-685$

Maniatis, T., Fritsch, E. F., Sambrook, J. (1982). Molecular cloning: a laboratory manual. Cold Spring Harbor Laboratory, Cold Spring Harbor, NY

Manton, I., Parke, M. (1960). Further observations on small green flagellates with special reference to possible relatives of Chromulina pusilla Butcher J. mar. biol. Ass. U.K. 39: $275-298$

Mayer, J. A. (1978). Isolation and ultrastructural study of a lytic virus in the small marine phytoflagellate Micromonas pusilla (Prasinophyceae). Ph.D. thesis, University of British Columbia

Mayer, J. A., Taylor, F. J. R. (1979). A virus which lyses the marine nanoflagellate Micromonas pusilla. Nature, Lond. 281: 299-301

Moebus, K. (1980). A method for the detection of bacteriophages from ocean water. Helgoländer Meeresunters. 34: $1-14$

Owen, R. W Jr (1974). Distribution of primary production, plant pigments and secchi depth in the California Current region, 1969. CalCOFI Atlas No. 20, State of California Marine Research Committee

Parsons, T R., Maita, Y., Lalli, C. M. (1984). A manual of chemical and biological methods for seawater analysis. Pergamon Press, New York

Pienaar, R. N. (1976). Viral-like infections in three species of phytoplankton from San Juan Island, Washington. Phycologia 15: 185-190

Proctor, L. M., Fuhrman, J. A. (1990). Viral mortality of marine bacteria and cyanobacteria. Nature, Lond. 343:60-62

Reanney, D. C., Ackermann, H. W. (1982). Comparative biology and evolution of bacteriophages. Adv. viral Res. 27: 205-280

Schuster, A. M., Burbank, D. E., Meister, B., Skrdla, M. P., Meints, R. H., Hattman, S., Swinton, D., Van Etten, J. L. (1986). Characterization of viruses infecting a eukaryotic Chlorella-like green alga. Virology 150: 170-177

Sieburth, J. McN., Johnson, P. W., Hargraves, P. E. (1988). Ultrastructure and ecology of Aureococcus anophagefferens gen. et. $\mathrm{sp}$. nov. (Chrysophyceae): The dominant picoplankter during a bloom in Narragansett Bay, Rhode Island, summer 1985. J. Phycol. 24:416-425

Spencer, R. (1963). Bacterial viruses in the sea. In: Oppenheimer, C. H. (ed.) Marine microbiology. Thomas, Illinois, p. $350-365$

This article was presented by D. A. Caron, Woods Hole, Massachusetts, USA
Starr, R. C., Zeikus, J. A. (1987). UTEX - The culture collection of algae at The University of Texas at Austin. J. Phycol. 23 (Suppl.): $1-47$

Stockner, J. G., Cliff, D. D., Shortreed, K. R. S. (1979). Phytoplankton ecology of the Strait of Georgia, British Columbia. J. Fish. Res. Bd Can. 36: 657-666

Studier, F. W. (1980). The last of the T phages. In: Horowitz, N. H., Hutchings, E. Jr (eds.) Genes, cells, and behavior W. H. Freeman, San Francisco, p. 72-78

Suttle, C. A., Chan, A. M., Cottrell, M. T (1990). Infection of phytoplankton by viruses and reduction of primary productivity. Nature, Lond. 347: 467-469

Suttle, C. A., Chan, A. M., Cottrell, M. T. (1991). Use of ultrafiltration to isolate viruses from seawater which are pathogens of marine phytoplankton. Appl environ. Microbiol. $57 \cdot 721-726$

Taylor, J. (1962). The estimation of numbers of bacteria by tenfold dilution series. J. appl. Bact. 25: 54-61

Throndsen, J. (1973). Phytoplankton occurrence and distribution on stations sampled during the SCOR WG 15 cruise to the Caribbean Sea, Pacific Ocean and Sargasso Sea in May 1970, based on direct cell counts. Data Report SCOR Discoverer Expedition May 1970, SIO Ref. 73-16 Univ. Calif., E 1-28

Throndsen, J. (1976). Occurrence and productivity of small marine flagellates. Norw. J. Bot. 23: 269-293

Van Etten, J. L., Burbank, D. E., Schuster, A. M., Meints, R. H. (1985). Lytic viruses infecting a Chlorella-like alga. Virology 140: $135-143$

Van Etten, J. L., Lane, L. C., Meints, R. H. (1991). Viruses and virus-like particles of eukaryotic algae. Microbiol. Rev. (in press)

Waters, R. E., Chan, A. T (1982). Micromonas pusilla virus: the virus growth cycle and associated physiological events within the host cells; host range mutation. J. gen. Virol. 63: 199-206

Wyllie, J. G., Lynn, R. J. (1971). Distribution of temperature and salinity at 10 meters, 1960-1969 and mean temperature, salinity and oxygen at 150 meters, 1950-1968 in the California Current. CaCOFI Atlas No. 15, State of California Marine Research Committee

Wiggins, B. A., Alexander, M. (1985). Minimum bacterial density for bacteriophage replication: implications for significance of bacteriophages in natural ecosystems. Appl. environ. Microbiol. 49: 19-23

Wray, W., Boulikas, T., Wray, V P., Hancock, R. (1981). Silver staining of proteins in polyacrylamide gels. Analyt. Biochem. 118: 197-203

Zhang, Y., Burbank, D. E., Van Etten, J. L. (1988). Chlorella virues isolated from China. Appl. environ. Microbiol. 54: $2170-2173$

Manuscript first received: June 10,1991

Revised version accepted: September 20, 1991 